\title{
APPLICATION OF DISTRIBUTED ANTENNA SYSTEMS FOR DETERMINATION OF RADIATION SOURCE COORDINATES WITH USE OF PHASE METHOD IN FRESNEL ZONE
}

\author{
Gleb L. Avdeyenko, Yevheniy A. Yakornov \\ Institute of Telecommunication Systems of National Technical University of Ukraine \\ "Igor Sikorsky Kyiv Polytechnic Institute", Kyiv, Ukraine
}

Background. Talking about evolution of passive radar systems and multifunction antenna systems, it is necessary to acknowledge that distributed antenna systems (DAS) are supposed to be widely spread in the very near future in many areas of human activity, such as organization of high-quality mobile communication in large offices, shopping centers, fitness buildings and so on. Structurally, DAS consist of different groups of antennas and base stations with active and passive repeaters of radio signals. Generally, mutual location of such antennas and base stations can be chosen experimentally according to the criterion of service area maximization. For the further quality of service improvement, it is necessary to use smart antennas in DAS as basic structure elements. The use of smart antennas will allow tracking the subscriber`s (or SOR - source of radiation) location by means of direction-finding (DF) and to increase radiation power of radio signal towards SOR thus decreasing interference to other subscribers. It is important to note that amplitude methods of DF are unacceptable in this case because base stations have antenna beam patterns which are rather wide. Use of phase methods for direction finding is actual but constrained because of electromagnetic waves (EMW) multipath propagation and large DF errors caused by the following reason - it happens that SOR is located in Fresnel zone of direction-finder antenna system. So, consideration of the phenomenon of EMW front curvature in DAS is very important in order to construct direction-finders.

Objective. Consideration of EMW phase front sphericity (curvature) and its influence on the accuracy of SOR coordinates determination measured by DAS phase methods. Scheme technical decisions of phase direction-finders (PDF) based on this process are also represented.

Methods. To study the effect of the EMW phase front curvature on the accuracy of determining the coordinates of the SOR analytical dependencies are synthesized. Calculations of the direction characteristics, errors in determining the phase shifts between the antenna elements of the phase direction-finder, as well as the error in determining the distance to SOR in the Fresnel zone as a function of the range to SOR and its bearing were made based on MathCad 14 program.

Results. During the process of SOR angular coordinates determination in Fresnel zone with use of EMW phase front curvature on the basis of planar antenna array, it is necessary to execute consistently two operations: 1) to define the fact of presence of EMW phase front curvature; 2) to switch PDF from the mode of bearing and tilt angles estimation (when it is in plane phase front) to the mode of bearing and tilt angles estimation (and also distance to SOR if needed) with phase front curvature of EMW.

Taking into account the analysis relating to errors of bearing angle measurements in Fresnel zone (depending on the location of rough, but exact bases, for three-element sparse LAA) it is possible to conclude that their position doesn't impact on exactness of bearing angle measuring in PDF. But to support more exact determination of SOR distance they must be placed in the center of exact, but ambiguous bases of PDF.

Conclusions. Failure to take into account EMW phase front curvature from SOR harmonic signal leads to errors of SOR coordinate calculation under conditions of its location in Fresnel zone and absence of other SORs. Knowledge of distance to SOR can be used in passive radar systems, in radio monitoring systems of radio interference sources which have bearing angles equal with useful SOR ones, but located on different distances from useful SOR. This knowledge can also be used in mobile communication networks to strengthen signal level on certain distance with EMW energy focusing, in vehicle control systems on the basis of the satellite navigation systems etc.

Keywords: source of radiation; phase direction-finder; curvature; phase front; antenna array; bearing angle; distance.

\section{Introduction}

Talking about evolution of passive radar systems [1] and multifunction antenna systems [2], it is necessary to acknowledge that distributed antenna systems $[3,4]$ are supposed to be widely spread in the very near future in many areas of human activity, such as organization of high-quality mobile communication in large offices, shopping centers, fitness buildings and so on.

Structurally, DAS consist of different groups of 
antennas and base stations with active and passive repeaters of radio signals. Generally, mutual location of such antennas and base stations can be chosen experimentally according to the criterion of service area maximization.

For the further quality of service improvement, it is necessary to use smart antennas in DAS as basic structure elements (as shown in [5]). The use of smart antennas will allow tracking the subscriber's (or SOR) location by means of direction-finding (DF) and to increase radiation power of radio signal towards SOR.

It is important to note that:

- amplitude methods of DF are unacceptable in this case because base stations have antenna beam patterns which are rather wide;

- use of phase methods is constrained because of electromagnetic waves (EMW) multipath propagation and large DF errors caused by the following reason - it happens that SOR is located in Fresnel zone of direction-finder antenna system. Deviation of EMW phase front is taking place inside of this zone, namely from plane one to curvature one, at the distance $d$, which satisfies $[6,7,8]$

$$
d_{N F Z} \leq d \leq d_{\mathrm{FFZ}},
$$

where $d_{\mathrm{FFZ}}=\frac{2 L^{2} \cos ^{2} \beta}{\lambda}$ is the border of far-field zone (FFZ) at which curvature of EMW phase front within the limits of LAA aperture does not exceed $\lambda / 16$ (phase error of radio signal carrier frequency between the extreme and central elements of LAA equals 22,5 degrees), $d_{\mathrm{NFZ}}=0,62 \sqrt{\frac{L^{3}}{\lambda}}$ is the border of near-field zone (NFZ), $L$ is the inter-element distance (base) of LAA, $\lambda$ is the wave-length.

Consideration of the phenomenon of EMW front curvature in DAS is also very important. If we choose configuration of LAA as two omnidirectional antennas, then base between them (i.e inter-element distance) should exceed the half of $\lambda$ significantly. It is caused by necessity to reduce DF mean square error (MSE). Thus, MSE in the case of phase direction-finder (PDF) with two antenna elements in accordance to [11] equals

$$
\sigma_{\beta}=\frac{\sigma_{\varphi}}{2 \pi \frac{L}{\lambda} \cos \beta},
$$

where $\beta$ is the SOR bearing angle, $\sigma_{\varphi}$ is the MSE of harmonic signal phase difference between PDF antennas.

Therefore, one of major advantages of PDF is evident from formula (2): an angular error of SOR bearing angle can be reduced to arbitrarily small value, but in case if relation $L / \lambda$ is sufficiently large at the fixed phase error due to many factors which cause this error such as:

- unideality of radiowave propagation environment, or/and

- unidentity of front ends from antennas to the phase meters (it causes appearance of phase changes which are not taken into account); or/and

- unideality of phase meters (particularly, appearance of quantization noise in case of its digital realization).

Since $\lambda$ in the applied radio systems relatively large (1..10 meters), it is necessary to increase $L$, that results in appearance of sphericity (curvatures) EMW phase front.

The article is organized as follows. Section 2 describes the theoretical background required for this study, i.e description of PDFs that use EMW phase front sphericity (curvature) and its influence on the accuracy of SOR coordinates determination measured by DAS phase systems. Scheme technical decisions of this process are also represented. Section 3 discusses PDF unambiguous base allocation impact on determination accuracy of SOR bearing angle and distance. Section 4 presents PDF based on plane antenna array application, and as a result Section 5 provides a summary and discussion of the results.

\section{Theoretical background}

At present time, most of developed PDF constructed on the basis of DAS are intended for processing of SOR harmonic signals. At the same time, overwhelming majority of the radio systems are using modulated signals, for example phase-shift keying. Therefore mathematical apparatus described below will be applicable only in case if procedure of preliminary conversion of modulated oscillation in harmonic one will be realized. Examples of devices that are able to implement such procedure are widely known and shown in [9].

We will begin review of EMW phase front curvature impact on PDF bearing angle errors with the example of single-station passive radar, executed on the basis of DAS. If we:

- use PDF with DAS [10] configurated as threeelement sparse LAA (Fig.1) to determine bearing angle, and

- conduct subsequent processing of harmonic signals received from SOR by PDF antennas for EMW plane phase front (i.e SOR is located in a FFZ of PDF antenna systems), it is possible to form direction-finder characteristic (DFC) of kind 


$$
F(\beta)=\operatorname{tg}\left(\frac{\pi \Delta L \sin \beta}{\lambda}\right),
$$

where $\Delta L=L_{32}-L_{21}$ - is the difference of lengths of bases of three-element LAA of PDF.

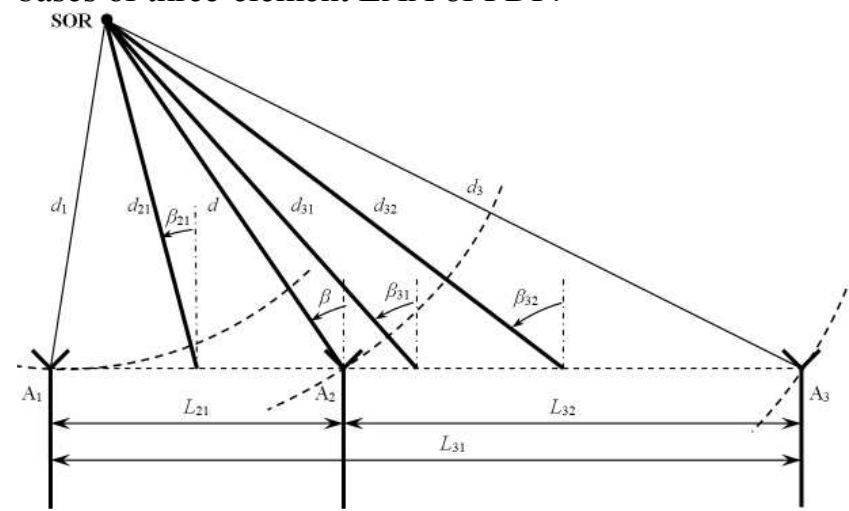

Fig.1 Phase direction-finder three-element LAA

Under condition $\Delta L=\lambda / 4$ the unambiguity of bearing angle measuring will be fully provided and DFC looks like

$$
F(\beta)=\operatorname{tg}\left(\frac{\pi \sin \beta}{4}\right)
$$

Under condition when $\beta=-90^{\circ} \ldots 90^{\circ}$, DFC maximum value changes from -1 to +1 .

In presence of EMW phase front curvature from SOR on the basis of [10] PDF looks like

$$
F(\beta)=\operatorname{tg}\left(\frac{1}{2}\left(\Delta \varphi_{32 \text { full }}-\Delta \varphi_{21 \text { full }}\right)\right),
$$

where $\Delta \varphi_{21 \text { full }}, \Delta \varphi_{32 \text { full }}$ are complete phase shifts of SOR signal carrier between the second and first, the third and second receiving PDF antennas, which accordingly to Fig. 1 will be equal to

$$
\begin{gathered}
\Delta \varphi_{21 \text { full }}=\frac{2 \pi\left(d-d_{1}\right)}{\lambda}, \\
\Delta \varphi_{32 \text { full }}=\frac{2 \pi\left(d_{3}-d\right)}{\lambda} .
\end{gathered}
$$

Taking into account that conditions $L_{21} / d \ll<1$, $L_{32} / d<<1$ can be realized in relation to SOR located in Fresnel zone of PDF antenna system in majority of cases, the next approximations using Taylor series are true in this zone

$$
\begin{aligned}
& d_{1}=\sqrt{d^{2}-2 d L_{21} \sin \beta+L_{21}^{2}} \approx d-L_{12} \sin \beta+\frac{L_{12}^{2} \cos ^{2} \beta}{2 d}, \\
& d_{3}=\sqrt{d^{2}+2 d L_{32} \sin \beta+L_{32}^{2}} \approx d+L_{32} \sin \beta+\frac{L_{32}^{2} \cos ^{2} \beta}{2 d} .
\end{aligned}
$$

In that case formulae (6), (7)

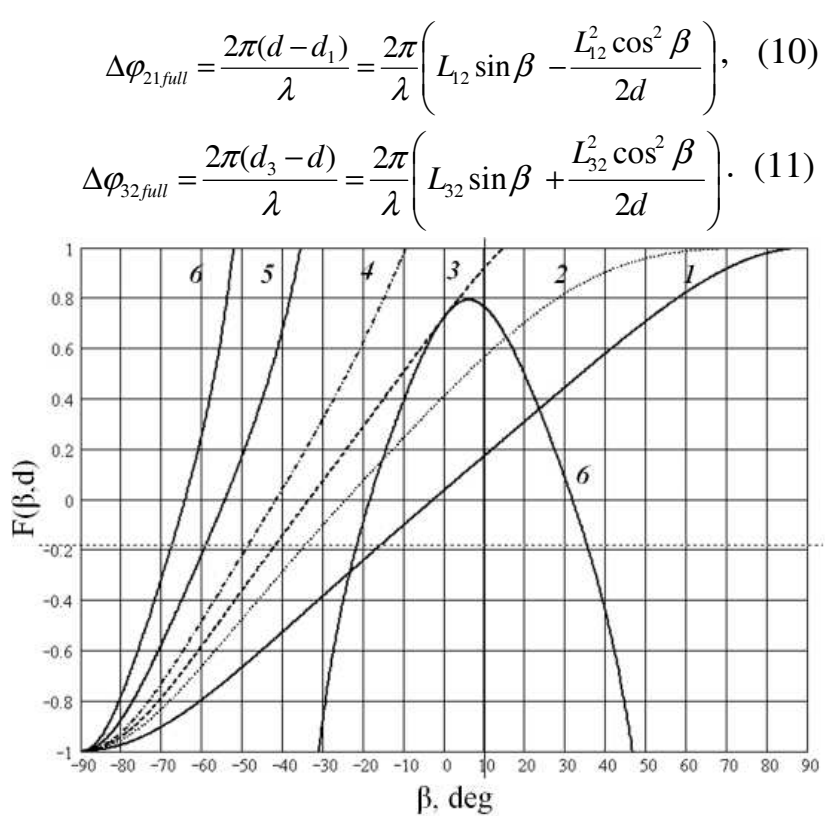

Fig.2 Direction-finder characteristics

In presence of EMW phase front curvature DFC will looks like

$$
F(\beta, d)=\operatorname{tg}\left\{\frac{\pi}{\lambda}\left[\left(L_{32}-L_{21}\right) \sin \beta+\frac{\left(L_{32}^{2}+L_{21}^{2}\right) \cos ^{2} \beta}{2 d}\right]\right\} .
$$

Thus, DFC begins to depend on distance to SOR, and consequently, becomes ambiguous. It indicates appearance of errors (Fig.2) in determination of bearing angle on the basis of the existent schemes of PDF configured as third-element LAA for SOR DF in Fresnel zone. From the PDF DFC plots, built in accordance with formula (12) for a harmonic signal and for information, resulted in tab.1, it is clear, that there are considerable errors in determination of bearing angle on the border of FFZ (curve №2). An error in determination of SOR bearing angle grows with diminishing of distance $d$ between LAA and SOR, that can happen at further deep advancement of SOR into Fresnel zone.

Table 1 Relation between SOR distances and curve number

\begin{tabular}{|c|c|c|c|c|c|c|}
\hline \multirow{3}{*}{$\begin{array}{c}\text { Parame } \\
\text { ters }\end{array}$} & \multicolumn{5}{|c|}{$f=10 \mathrm{GHz}, L_{21}=1000 \lambda=30 m, L_{32}=1000,25 \lambda=30,008 m$} \\
\cline { 2 - 7 } & $10 d_{\mathrm{FFZ}}$ & $d_{\mathrm{FFZ}}$ & $0,6 d_{\mathrm{FFZ}}$ & $0,4 d_{\mathrm{FFZ}}$ & $0,2 d_{\mathrm{FFZ}}$ & $0,1 d_{\mathrm{FFZ}}$ \\
\hline $\begin{array}{c}\text { № of } \\
\text { curve }\end{array}$ & 1 & 2 & 3 & 4 & 5 & 6 \\
\hline
\end{tabular}

The second element in formula (12) is inversely proportional to distance $d$ and introduces error in DFC (1) which becomes greater, when SOR is located nearer to the direction-finder (formula (12) transforms to (4) when $d \rightarrow \infty$ ). 
Further we will analyze influence of EMW phase front curvature at determination of bearing angle on the basis of LAA for a mobile radio communication system using [11] (only in large office apartments without the account of multipath transmission of radio waves).

First of all, we will consider the error of determination of SOR bearing angle of harmonic signal when we use PDF with two scales for phases measuring: unambiguous, but rough with a base $L_{21}=\lambda / 2$, and ambiguous but accurate with a base $L_{43}=n \lambda / 2$, where $n \gg 1$. In this case unambiguous base is placed in a center of ambiguous one (Fig.3). We will suppose that errors of phase measuring is absent or compensated during calibration. Each antenna element is omnidirectional.

Case A. Signal from SOR has plane phase front on PDF aperture.

In this case, we will get the signal of kind (13) at the output of the first phase meter $\left(\mathrm{Ph}_{1}\right)$, executed, for example, on the basis of phase detector (PD),

$$
U_{\mathrm{Ph}_{1}}=K_{D} U_{m} \cos \left(\Delta \varphi_{21 \text { meas }}\right),
$$

where $K_{D}$ is the FD gain; $U_{m}$ is the amplitude of the accepted radio signal; $\Delta \varphi_{21 \text { meas }}$ is the measured phase difference between the nearby elements of unambiguous base $L_{21}$ of PDF LAA which equals

$$
\Delta \varphi_{21 \text { meas }}=\frac{2 \pi L_{21} \sin \beta}{\lambda} \text {. }
$$

Under condition $\beta=-90^{\circ} \ldots 90^{\circ}$ we get that $\Delta \varphi_{21 \text { meas }}=-\pi \ldots \pi$.

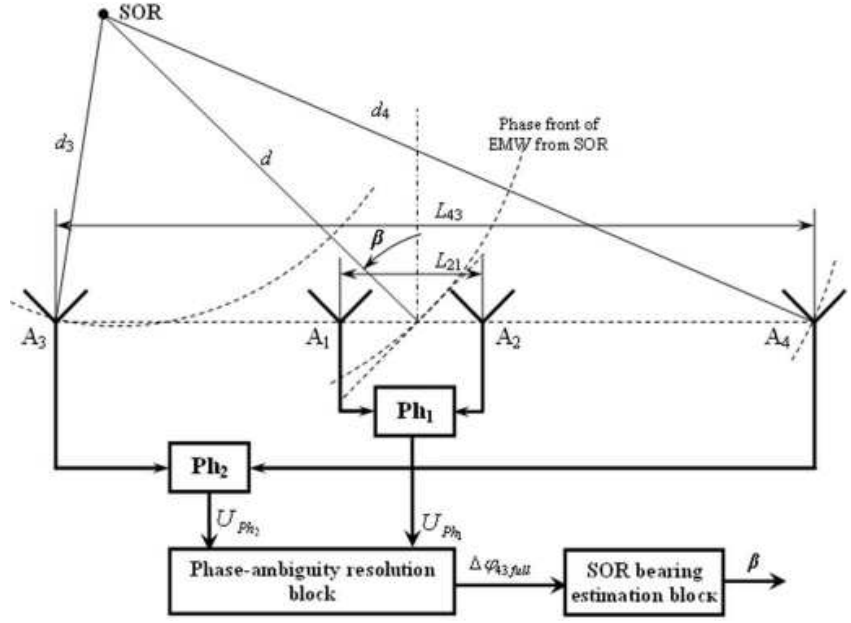

Fig.3 Phase direction-finder structure scheme with two scales

At the output of the second phase meter $\left(\mathrm{Ph}_{2}\right)$, will get the signal of kind

$$
U_{\mathrm{Ph}_{2}}=K_{D} U_{m} \cos \left(\Delta \varphi_{43 \text { meas }}\right),
$$

where $\Delta \varphi_{43 \text { meas }}$ is a difference of phases, measured by phase meter on an accurate, but ambiguous base $L_{43}$ of LAA, where $\left|\Delta \varphi_{43 \text { meas }}\right| \leq \pi$.

Complete difference of phases for an ambiguous base

$$
\Delta \varphi_{43 \text { full }}=\frac{2 \pi L_{43} \sin \beta}{\lambda}=\Delta \varphi_{43 \text { meas }}+2 \pi k_{43}
$$

where $k_{43}$ is a coefficient, showing the number of complete periods which was lost at measurements in phase meter.

From formulae (4) and (6), taking into account, that $\Delta \varphi_{43 \text { full }}=\frac{L_{43}}{L_{21}} \Delta \varphi_{21 \text { meas }}$ we get, that

$$
k_{43}=\left\langle\frac{1}{2 \pi}\left(\frac{L_{43}}{L_{21}} \Delta \varphi_{21 \text { meas }}-\Delta \varphi_{43 \text { meas }}\right)\right\rangle,
$$

where $\langle\cdot\rangle$ is the operation of rounding off to the nearest whole number.

Then

$\beta=\arcsin \left(\frac{\lambda}{2 \pi L_{43}}\left(\Delta \varphi_{43 \text { full }}\right)\right)=\arcsin \left(\frac{\lambda}{2 \pi L_{43}}\left(\Delta \varphi_{43 \text { meas }}+2 \pi k_{43}\right)\right)$.

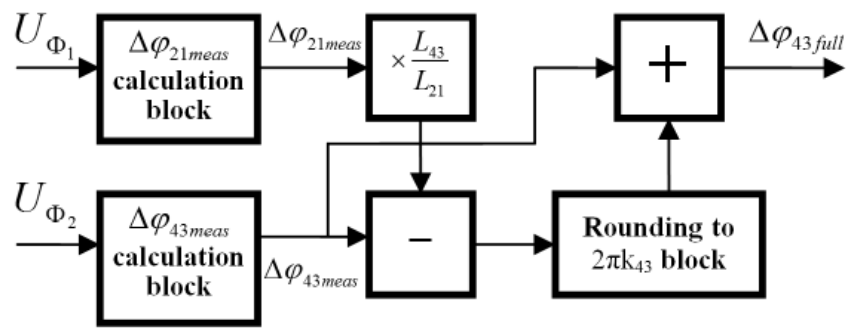

Fig.4 Phase-ambiguity resolution block simplified schematic diagram

The algorithm (16) will be realized in the phaseambiguity resolution block (Fig.3), the simplified schematic diagram of which is shown on Fig.4.

Case B. Electromagnetic wave phase front from SOR for phase difference measuring when PDF operates on the unambiguous scale $L_{21}$ is plane. During operation on an ambiguous scale $L_{43}$ phase front is spherical.

In this case we get

$$
\Delta \varphi_{43 \text { full }}=\frac{2 \pi\left(d_{4}-d_{3}\right)}{\lambda},
$$

where $d_{3}, d_{4}$ are distances from SOR to PDF's antennas $\mathrm{A}_{3}$ and $\mathrm{A}_{4}$, which are accordingly equal to 


$$
\begin{aligned}
& d_{3}=\sqrt{d^{2}-L_{43} \sin \beta+0,25 L_{43}^{2}}, \\
& d_{4}=\sqrt{d^{2}+L_{43} \sin \beta+0,25 L_{43}^{2}},
\end{aligned}
$$

where $d$ and $\beta$ are the distance and SOR bearing angle accordingly, measured in relation to the center of LAA base.

From [6] it is known that if relation of overall sizes of the antenna system toward distance to SOR is small, that is $L_{43} / d<<1$, then it is possible to be limited to the members of the second order to the trifle at Taylor series decomposition (20) and (21) (so-called Fresnel approximation) in Fresnel zone

$$
\begin{aligned}
& d_{3} \approx d-\frac{L_{43}}{2} \sin \beta+\frac{L_{43}^{2} \cos ^{2} \beta}{8 d}, \\
& d_{4} \approx d+\frac{L_{43}}{2} \sin \beta+\frac{L_{43}^{2} \cos ^{2} \beta}{8 d} .
\end{aligned}
$$

Then putting (22) and (23) in (19) will get, that

$$
\Delta \varphi_{43 \text { full }}=\frac{2 \pi L_{43} \sin \beta}{\lambda}
$$

Therefore, it is possible to confirm that sphericity of EMW phase front at LAA aperture, specified by SOR location in Fresnel zone, doesn't impact on exactness of bearing angle calculation (for PDF, consisting of set two sparse antennas). So, the value of bearing angle does not depend on the type of phase front and its calculation is produced on the same formulas (17) and (18) as for the case when EMW phase front is plane.

Error in determination of phase difference between LAA elements $A_{3}$ and $A_{4}$ (Fig.1) without consideration of higher order of trifle in $[17,18]$ looks like [8]

$$
\delta \Delta \varphi_{43}=\frac{2 \pi}{\lambda}\left[L_{43} \sin \beta-\left(\sqrt{d^{2}+L_{43} \sin \beta+0,25 L_{43}^{2}}-\sqrt{d^{2}-L_{43} \sin \beta+0,25 L_{43}^{2}}\right)\right]
$$

Fig.5 represents charts of error dependence in determination of SOR harmonic signal phase difference between LAA elements $\mathrm{A}_{3}$ and $\mathrm{A}_{4}$ according to formula (25). This dependence is impacted by bearing angle and distance to SOR, where carrier frequency of signal equals $f=10 \mathrm{GHz}(\lambda=0,03 \mathrm{~m})$ ). Also, base $L=1000 \lambda$ and distances to SOR equal $1 \mathrm{~km}, 5 \mathrm{~km}, 50 \mathrm{~km}$ and 100 $\mathrm{km}$. According to [6], the border of NFZ comes to $d_{N F Z} \approx 584 \mathrm{~m}$ and the border of FFZ equals $d_{F F Z} \approx 60 \mathrm{~km}$. Thus, extension of intermediate zone (i.e Fresnel zone) equals $\Delta d_{\mathrm{IZ}}=d_{\mathrm{FFZ}}-d_{\mathrm{NFZ}} \approx 59,5 \mathrm{~km}$.

From Fig.5 it is also evident, that nearer SOR to the border of NFZ is located, more error value we have when determinate difference between PDF antennas. Main reason it happens - calculations don't consider members of more high order of trifle in Taylor series decomposition.

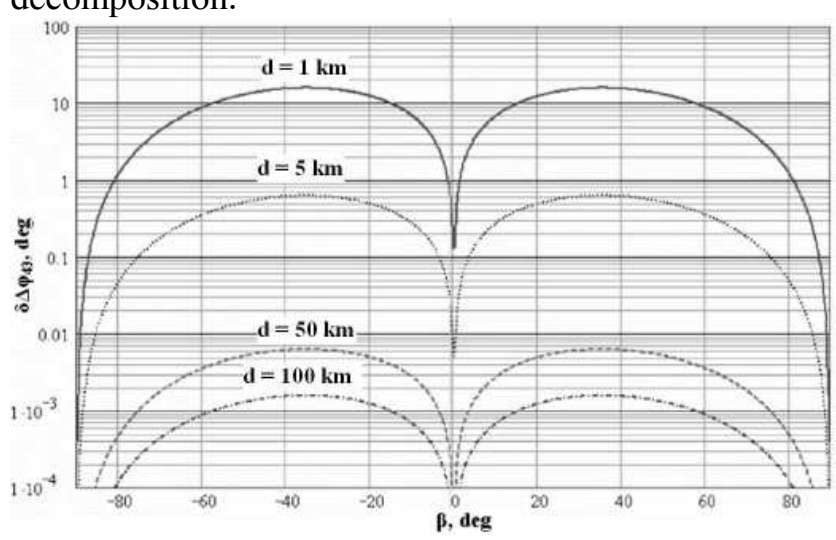

Fig.5 Phase difference error dependence between LAA elements

Let us consider PDF, which is used in practice very often. It uses three-element LAA (Fig.1). In its turn, this LAA can be represented as a combination of two independent PDFs with two-element LAA and bases $L_{21}$ and $L_{32}$ accordingly. Then taking into account that formulae $L_{21} / d_{21} \ll<1, \quad L_{32} / d_{32} \ll<1, \quad L_{31} / d_{31}<<1$ are true in Fresnel zone and considering formulae (12) and (13) we will get, that

$$
\begin{gathered}
d_{1}=\sqrt{d_{21}^{2}-d_{21} L_{21} \sin \beta_{21}+0,25 L_{21}^{2}} \approx d_{21}-\frac{L_{21}}{2} \sin \beta_{21}+\frac{L_{12}^{2} \cos ^{2} \beta_{21}}{8 d_{21}}, \\
d=\sqrt{d_{21}^{2}+d_{21} L_{21} \sin \beta_{21}+0,25 L_{21}^{2}} \approx d_{21}+\frac{L_{21}}{2} \sin \beta_{21}+\frac{L_{21}^{2} \cos ^{2} \beta_{21}}{8 d_{21}} .
\end{gathered}
$$

Then complete phase difference between the second and the first elements of LAA equals

$$
\Delta \varphi_{21 \text { full }}=\frac{2 \pi\left(d-d_{1}\right)}{\lambda}=\frac{2 \pi L_{21} \sin \beta_{21}}{\lambda} .
$$

In its turn, using Taylor series we can write, that

$$
\begin{gathered}
d_{3}=\sqrt{d_{32}^{2}+d_{32} L_{32} \sin \beta_{32}+0,25 L_{32}^{2}} \approx d_{32}+\frac{L_{32}}{2} \sin \beta_{32}+\frac{L_{32}^{2} \cos ^{2} \beta_{32}}{8 d_{32}}, \\
d=\sqrt{d_{32}^{2}-d_{32} L_{32} \sin \beta_{32}+0,25 L_{32}^{2}} \approx d_{32}-\frac{L_{32}}{2} \sin \beta_{32}+\frac{L_{32}^{2} \cos ^{2} \beta_{32}}{8 d_{32}} .
\end{gathered}
$$

In that case, full phase shift between third and second LAA elements

$$
\Delta \varphi_{32 \text { full }}=\frac{2 \pi\left(d_{3}-d\right)}{\lambda}=\frac{2 \pi L_{32} \sin \beta_{32}}{\lambda} .
$$

Besides,

$$
\begin{aligned}
& d_{1}=\sqrt{d_{31}^{2}-d_{31} L_{31} \sin \beta_{31}+0,25 L_{31}^{2}} \approx d_{31}-\frac{L_{31}}{2} \sin \beta_{31}+\frac{L_{31}^{2} \cos ^{2} \beta_{31}}{8 d_{31}}, \\
& d_{3}=\sqrt{d_{31}^{2}+d_{31} L_{31} \sin \beta_{31}+0,25 L_{31}^{2}} \approx d_{31}+\frac{L_{31}}{2} \sin \beta_{31}+\frac{L_{31}^{2} \cos ^{2} \beta_{31} .}{8 d_{31}} .
\end{aligned}
$$

Then the full phase shift between the third and the first LAA elements

$$
\Delta \varphi_{31 \text { full }}=\frac{2 \pi\left(d_{3}-d_{1}\right)}{\lambda}=\frac{2 \pi L_{31} \sin \beta_{31} .}{\lambda} .
$$


Obviously, that when plane front of EMW from SOR arrives on PDF LAA, according to Fig.1 next formulae are true, such as

$$
\begin{aligned}
& \beta=\beta_{21}=\beta_{32}=\beta_{31}, \\
& \Delta \varphi_{21 \text { full }}=\Delta \varphi_{32 \text { full }} \frac{L_{21}}{L_{32}}=\Delta \varphi_{31 \text { ffull }} \frac{L_{21}}{L_{31}} .
\end{aligned}
$$

Thus, if formula (35) or (36) is not true, it can be assumed that phase front of EMW from SOR is spherical, not plane.

More comfortable way to implement procedure of verification is to analyze the differences of phases between the first and second $\left(\Delta \varphi_{21}\right)$, the second and third $\left(\Delta \varphi_{32}\right)$ pair of antennas when EMW phase front is plane, taking into account a difference in bases $\Delta L=L_{32}-L_{21}$. For this purpose let us take a relation $\frac{\Delta \varphi_{32}}{\Delta \varphi_{21}}=\frac{2 \pi L_{32} \sin \beta}{\lambda} \frac{\lambda}{2 \pi L_{21} \sin \beta}=\frac{L_{32}}{L_{21}}=\frac{L_{21}+\Delta L}{L_{21}}=1+\frac{\Delta L}{L_{21}}=1+\delta$ where $\delta=\Delta L / L_{21}$.

So, according to (37) we can write $\Delta \varphi_{32}=\Delta \varphi_{21}+\delta \Delta \varphi_{21}$, from which

$$
\cos \left(\Delta \phi_{32}\right)=\cos \left(\Delta \phi_{21}\right) \cos \left(\delta \Delta \phi_{21}\right)-\sin \left(\Delta \phi_{21}\right) \sin \left(\delta \Delta \phi_{21}\right) .
$$

This equation is true for plane phase front of EMW for different bases between the pair of antennas.

Since phase detectors, presented in the PDF (Fig.3), form voltages (13), which are proportional to $\sin \left(\Delta \varphi_{21}\right), \cos \left(\Delta \varphi_{21}\right)$ and $\cos \left(\Delta \varphi_{32}\right)$, then it is necessary to form factors $\cos \left(\delta \Delta \varphi_{21}\right)$ and $\sin \left(\delta \Delta \varphi_{21}\right)$ for verification of equation (36).

Taking into account, that

$$
\begin{gathered}
\Delta \varphi_{21 \text { full }}=\Delta \varphi_{21 \text { meas }}+2 \pi k_{21}, \\
\Delta \varphi_{32 \text { full }}=\Delta \varphi_{32 \text { meas }}+2 \pi k_{32},
\end{gathered}
$$

phase shifts that have been measured by phase meters between the second and first, the third and second PDF antennas (using bases $L_{21}$ and $L_{32}$ ); $k_{21}, k_{32}$ it is an amount of phase periods, which are lost during phase measuring, it is possible to realize procedure of verification as implementation of equation (36).

For determination of $k_{21}, k_{32}$ it is possible to take advantage of the known method [11] namely: to introduct few pairs of antennas with a base $\lambda / 2$ to considered PDF (that is application of rough, but unambiguous scales of phase shift measuring). Then

$$
k_{21}=\left\langle\frac{1}{2 \pi}\left(\frac{L_{21}}{\mathrm{~L}_{\mathrm{r}}} \Delta \varphi_{r 21}-\Delta \varphi_{21 \text { meas }}\right)\right\rangle,
$$

$$
k_{32}=\left\langle\frac{1}{2 \pi}\left(\frac{L_{32}}{\mathrm{~L}_{\mathrm{r}}} \Delta \varphi_{r 32}-\Delta \varphi_{32 \text { meas }}\right)\right\rangle,
$$

where $\Delta \varphi_{r 21}, \Delta \varphi_{r 32}$ are phase shifts, measured with using the proper unambiguous bases $L_{r}=\lambda / 2$.

\section{Impact of phase direction-finder unambiguous base allocation on determination accuracy of SOR bearing angle and distance}

We will analyze location of unambiguous base $L_{r}$ in LAA with the purpose of possible optimization (diminishing) of PDF elements number for SOR bearing angle and distance determination at presence of curvature of phase front of EMW from this SOR.

The left part of Fig.1 with PDF LAA is represented at the Fig.6, where shading marks classic position of rough, but unambiguous base, formed with using antennas $\mathrm{A}_{3}$ and $\mathrm{A}_{4}$ (base $\mathrm{L}_{\text {bor }}$ ). We will consider how accuracy of SOR coordinate determination will be changed, if rough scale is moved to the PDF central antenna element of $\mathrm{A}_{2}$.

Assuming that EMW phase front within the borders of rough, but unambiguous base, is locally plane, phase shift at the classic construction of scales of PDF (a scale is between $\mathrm{A}_{3}$ and $\mathrm{A}_{4}$ ) equals

$$
\Delta \varphi_{r 43}(\beta, \mathrm{d})=\frac{2 \pi L_{\mathrm{r}} \sin \left(\beta_{21}(\beta, d)\right)}{\lambda},
$$

and a phase shift for the case of using the «optimum» chart of rough scale forming (a scale is between $\mathrm{A}_{2}$ and $\mathrm{A}_{5}$ )

$$
\Delta \varphi_{r 25}(\beta, \mathrm{d})=\frac{2 \pi L_{\mathrm{r}} \sin \left(\beta_{25}(\beta, \mathrm{d})\right)}{\lambda} .
$$

Taking into account previous equations (18), proper phase shift between the elements of $\mathrm{A}_{1}$ and $\mathrm{A}_{2}$

$$
\Delta \varphi_{21}(\beta, \mathrm{d})=\frac{2 \pi\left(d-d_{1}\right)}{\lambda}=\frac{2 \pi L_{21} \sin \left(\beta_{21}(\beta, d)\right)}{\lambda} .
$$

At Fig.6 approximation of spherical phase front from SOR by plane phase front is also shown on the base $L_{21}$, which symmetric relatively for both bases $L_{21}$ and $\mathrm{L}_{\mathrm{r}}$. In this case $\mathrm{OC}=\mathrm{OB}=\mathrm{r}$. Since point of $\mathrm{E}$ is a center of base of $L_{21}$, and also taking into account, that $\mathrm{DE}=\mathrm{EF}$ and $\mathrm{OE}$ athwart to $\mathrm{DF}$, it is possible to assert that $C D=B F=\Delta d_{1}=\Delta d_{2}$. That is value of errors in the differences of EMW motion during approximation of spherical phase front by plane phase front are identical modulo, but have different signs.

From there it is possible to assert that a phase shift between neighboring antenna elements (in this case, it is $A_{1}$ and $A_{2}$ ) does not depend on distance of $d_{21}$ to SOR, count out in relation to a center base of $\mathrm{L}_{21}$ (and 
accordingly center of rough base of $\mathrm{A}_{3}$ and $\mathrm{A}_{4}$ ). It happens because equality of EMW motion differences $\left(\Delta \mathrm{d}_{1}=\Delta \mathrm{d}_{2}\right)$ causes cancellation of quadratic shifts and the ones of higher order (at the process of calculation of signal phases differences between $A_{1}$ and $A_{2}$ ). As a result, it causes phase front curvature.

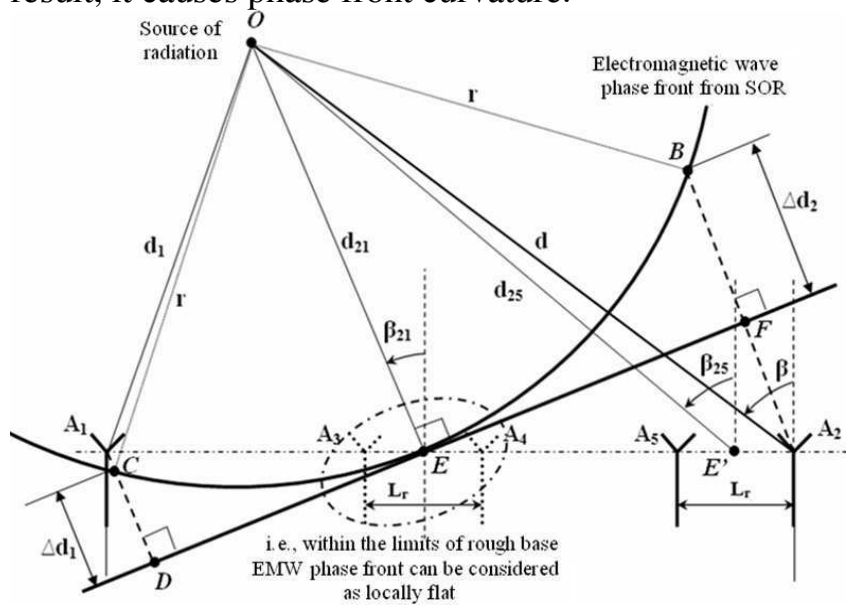

Fig.6 Curvature of EMW phase front approximation by plane phase front

However, above-mentioned phase difference depends linearly on bearing angle $\beta_{21}$, that must be counted from the center of base. Thus, spherical phase front influence is fully equivalent to EMW plane phase front action in this case. This phase front action does not arrive from direction $\beta$, but from direction $\beta_{21}$, which in turn depends on the real bearing $\beta$ and distance of $d$ to SOR, i.e $\beta_{21}=f(\beta, d)$.

Analogical approximation of spherical phase front shows that $\Delta \mathrm{d}_{1} \neq \Delta \mathrm{d}_{2}$, and there is no complete cancellation of quadratic phase shifts and phase shifts of higher orders. In this case it is assumed that plane phase front is asymmetrical in relation to the base of $\mathrm{L}_{21}$, but symmetrical in relation to the base of antenna elements of $\mathrm{A}_{2}$ and $\mathrm{A}_{5}$. And that is why such approximation of spherical front plane is incorrect, because it leads to error during the phase shift calculation.

Obviously, that error in the calculation of phase shift on a rough scale can be evaluated by using next formula (in case if formed by antennas of $A_{2}$ and $A_{5}$ (asymmetrical rough scale), $\mathrm{A}_{3}$ and $\mathrm{A}_{4}$ (symmetric rough scale)).

$$
\Delta \Delta \phi_{r 21}(\beta, \mathrm{d})=\Delta \phi_{r 43}(\beta, d)-\Delta \phi_{r 25}(\beta, d)=\frac{\left.\left.2 \pi L_{\mathrm{r}}\left[\sin \left(\beta_{21}(\beta, d)\right)-\sin \left(\beta_{25}\right) \beta, d\right)\right)\right]}{\lambda} .
$$

For finding of formula for the first sine in (46) triangle $\mathrm{OA}_{2} \mathrm{E}$ we will get, that (Fig.6)

$$
d_{21}=\sqrt{d^{2}-d L_{21} \sin \beta+\left(0,5 L_{21}\right)^{2}},
$$

$$
\begin{aligned}
& \frac{d_{21}}{\sin \left(90^{\circ}-\beta\right)}=\frac{d}{\sin \left(90^{\circ}+\beta_{21}\right)} \text {. From this it follows that } \\
& \cos \left(\beta_{21}\right)=\frac{d \cos \beta}{d_{21}} \\
& \sin \left(\beta_{21}(\beta, d)\right)=\sqrt{\frac{d_{21}^{2}-d^{2} \cos ^{2} \beta}{d_{21}^{2}}}=\sqrt{\frac{\left(0,5 L_{21}\right)^{2}+d^{2} \sin ^{2} \beta-L_{21} d \sin \beta}{\left(0,5 L_{21}\right)^{2}+d^{2}-L_{21} d \sin \beta}} \text {. (48) }
\end{aligned}
$$

In a similar manner from triangle $\mathrm{OA}_{2} \mathrm{E}^{\prime}$ we get

$$
\sin \left(\beta_{25}(\beta, d)\right)=\sqrt{\frac{d_{25}^{2}-d^{2} \cos ^{2} \beta}{d_{25}^{2}}}=\sqrt{\frac{\left(0,5 L_{\mathrm{r}}\right)^{2}+d^{2} \sin ^{2} \beta-L_{\mathrm{r}} d \sin \beta}{\left(0,5 L_{\mathrm{r}}\right)^{2}+d^{2}-L_{\mathrm{r}} d \sin \beta}} .
$$

In accordance with formulae (46)-(49) the graphic charts of phase errors response depending on SOR distance $d$ and bearing angle $\beta$, are shown at Fig.7 (it's important to note that they are counted out from central antenna of PDF at $\mathrm{L}_{21}=1000 \lambda$ and $\lambda=0,03 \mathrm{~m}$ ). From charts on Fig.7 it is evident, that error of calculation of phase shift diminishes, approaching to zero.

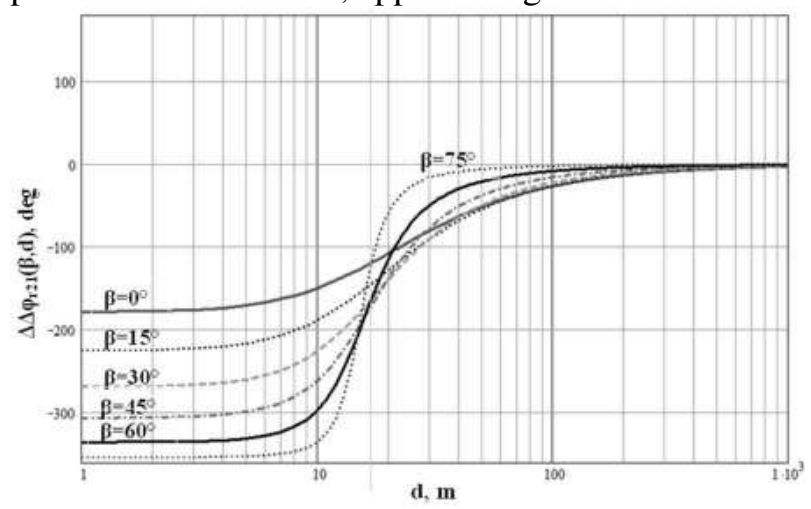

Fig.7 Phase error response as function of SOR distance and bearing angle

Now, let us consider potential errors taking place during measurements of phase shifts. This errors occur due to the loss of complete periods of harmonic radio signal phase. Obviously, in accordance with (16) next formulae are true in case of use of symmetric rough scale of $\mathrm{A}_{3}, \mathrm{~A}_{4}$ (Fig.3)

$$
\begin{gathered}
\Delta \varphi_{21 S Y M}(\beta, d)=\Delta \varphi_{21 \text { meas }}(\beta, d)+2 \pi k_{21 S Y M}(\beta, d), \\
\Delta \varphi_{21 S Y M}(\beta, d)=\frac{L_{21}}{L_{\mathrm{r}}} \Delta \varphi_{r 43}(\beta, d),
\end{gathered}
$$

where $\Delta \varphi_{21 \text { meas }}(\beta, d)$ is the harmonic radio signal phase shift, which measured by using phase detector between antennas $\mathrm{A}_{2}$ and $\mathrm{A}_{1}$ accordingly, $k_{21 S Y M}(\beta, d)$ is the coefficient, which takes into account the amount of the lost complete periods of phase of harmonic radio signal.

Formula for this coefficient according to (17) and (41) looks like

$$
k_{21 S Y M}(\beta, d)=\frac{1}{2 \pi}\left\langle\frac{L_{21}}{L_{\mathrm{r}}} \Delta \varphi_{r 43}(\beta, d)-\Delta \varphi_{21 \text { meas }}(\beta, d)\right\rangle,
$$


For the case of use asymmetrical rough scale of $\mathrm{A}_{2}, \mathrm{~A}_{5}$ (Fig.6) we can write by analogy with (50)

$$
\begin{aligned}
& \Delta \varphi_{21 N S Y M}(\beta, d)=\Delta \varphi_{21 \text { meas }}(\beta, d)+2 \pi k_{21 N S Y M}(\beta, d), \\
& \Delta \varphi_{21 N S Y M}(\beta, d)=\frac{L_{21}}{L_{\mathrm{r}}} \Delta \varphi_{r 25}(\beta, d),
\end{aligned}
$$

from there amount of the lost complete periods of phase of harmonic radio signal equals

$$
k_{21 N S Y M}(\beta, d)=\frac{1}{2 \pi}\left\langle\frac{L_{21}}{L_{\mathrm{r}}} \Delta \varphi_{r 25}(\beta, d)-\Delta \varphi_{21 \text { meas }}(\beta, d)\right\rangle .
$$

$$
\text { Taking into account, }
$$

$\Delta \varphi_{21 N S Y}(\beta, d) \neq \Delta \varphi_{21 S Y M}(\beta, d)$, an error in an amount of the complete periods of phase will be equal to

$$
\Delta k_{21}(\beta, d)=k_{215 M M}(\beta, d)-k_{21 N S M M}(\beta, d)=\frac{1}{2 \pi}\left\langle\frac{L_{21}}{L_{\mathrm{r}}} \Delta \Delta \varphi_{r 21}(\beta, d)\right\rangle .
$$

There are the resulted graphs of dependence $\Delta k_{21}(\beta, d)$ from distance $d$ and bearing angle $\beta$ at $\mathrm{L}_{21}=1000 \lambda \mathrm{i} \lambda=0,03 \mathrm{~m}$ on Fig. 8 .

It is evident from charts on Fig.8, that charts character coincides with graphic charts on Fig.7. It means that error of calculation of phase shift and error of amount of the lost complete periods approaches to zero (when distance $d$ between PDF and SOR increases and EMW phase front transforms from spherical into plane one).

Like the above-mentioned, results of errors analysis performed for right part (Fig.1) of PDF LAA are resulted on Fig. 9,a,b (for $L_{32}=1000,25 \lambda$ and $\lambda=0,03$ $\mathrm{m})$.

An error of bearing angle measuring for the asymmetrical rough scales of PDF equals

$$
\Delta \beta(\beta, d)=\left|\beta-\beta_{1}(\beta, d)\right|
$$

where $\beta$ is the actual bearing angle of $\operatorname{SOR}, \beta_{1}(\beta, d)$ is bearing angle of SOR, calculated with taking into account errors in complete phase shifts between the

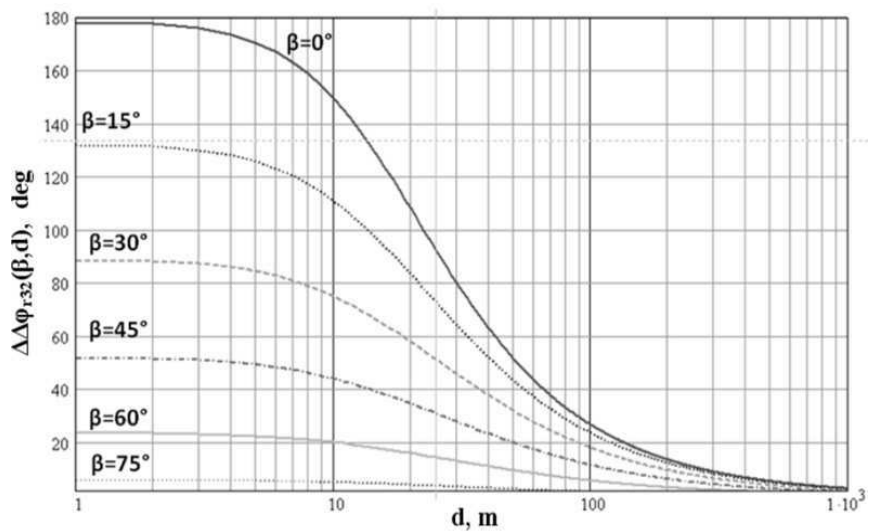

a) proper elements of PDF, in other words

$$
\beta_{1}(\beta, d)=\arcsin \left(\frac{\lambda\left(\Delta \varphi_{32 N S Y M}(\beta, d) L_{21}^{2}+\Delta \varphi_{21 N S Y M}(\beta, d) L_{32}^{2}\right)}{2 \pi L_{21} L_{32}\left(L_{21}+L_{32}\right)}\right)
$$

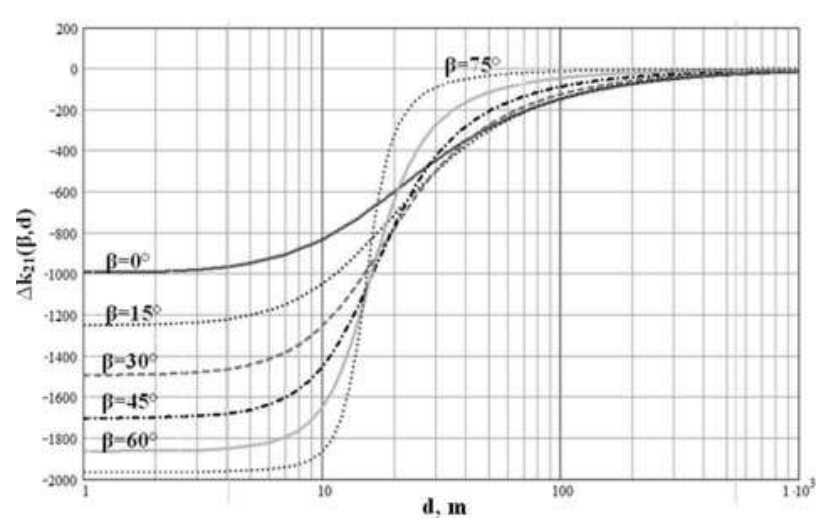

Fig. 8 Amount of the lost complete periods of phase as function of SOR distance and bearing angle.

Error of measuring of distance between actual $d$ and the expected (calculated) $d_{1}(\beta, d)$ value of distance to SOR when symmetric rough scales are used

$$
\Delta d_{1}(\beta, d)=\left|d-d_{1}(\beta, d)\right|
$$

where

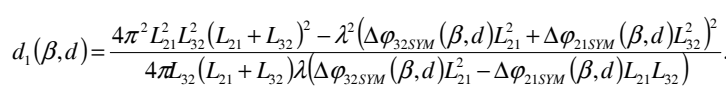

Similarly, error of distance measuring for the case of the use of asymmetrical rough scales

$$
\Delta d_{2}(\beta, d)=\left|d-d_{2}(\beta, d)\right|
$$

where $d_{2}(\beta, d)$ calculated the same as $(60)$, but it is necessary to change $\Delta \varphi_{21 S Y M}$ to $\Delta \varphi_{21 N S Y M}$, and $\Delta \varphi_{32 S Y M}$ on $\Delta \varphi_{32 N S Y M}$.

The graphic charts for $\Delta \beta(\beta, d)$ are shown at Fig.10,a.

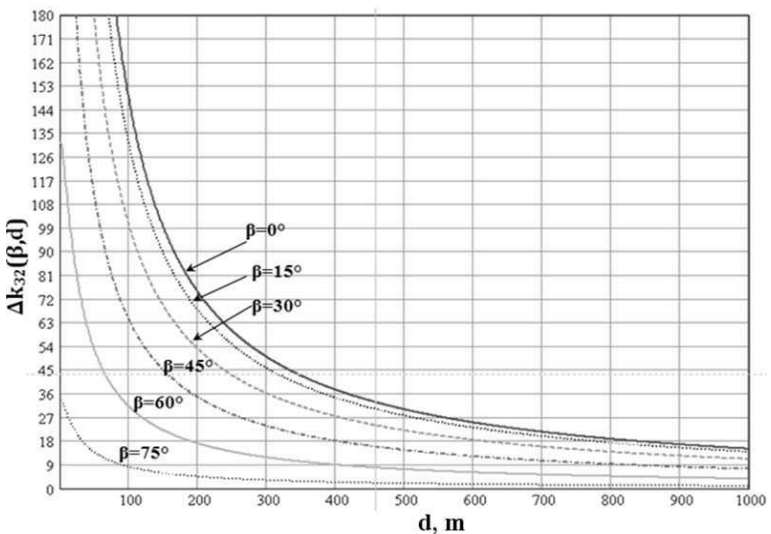

b)

Fig.9: a) Phase error response and b) amount of the lost complete periods as function of SOR distance and bearing angle. 
It is evident from Fig.10,a that errors of phase shifts calculation for an asymmetrical scale (specified by $k_{21}, k_{32}$ in case if they are incorrectly calculated) do not impact on precision of SOR bearing angle calculation. In our view, it can be explained by heteropolar changes of errors $\Delta k_{21}(\beta, d)$ and $\Delta k_{32}(\beta, d)$, that in its turn lead to their mutual cancellation under the sign of arcsine in a formula (58).

The graphic charts of dependence of distance error measuring from which it is evident that the distance error measuring very small, practically equals to zero (for the case of the symmetric placing of rough scale are resulted on Fig.10,b).

There are graphic charts of dependence of distance error measuring as function of the SOR distance and bearing angle on Fig.11, for the case of the asymmetrical placing of rough scale. It is evident from them, that the error of measuring of $d$ is very large. But beginning from some critical value of $d$, that depends on $\beta$, the distance error measuring falls to the zero.

Thus, the results of mathematical simulation show that the asymmetrical placing of rough bases for minimization of number of the involved antenna elements in Fresnel zone almost without errors allows to determining SOR bearing at presence of EMW phase front curvature. But errors minimum take place only for the case of symmetric location of bases, but for case of distance measuring with using curvature.

Therefore it is necessary to use classic [11] symmetric scheme of placing of rough, but unambiguous bases (scales) into exact bases for distance measuring. But it is hard to realize in practice this placing due to the finite overall sizes of omnidirectional antennas, since it is problematic to provide their placing in the distance $L_{r}=0,5 \lambda$.

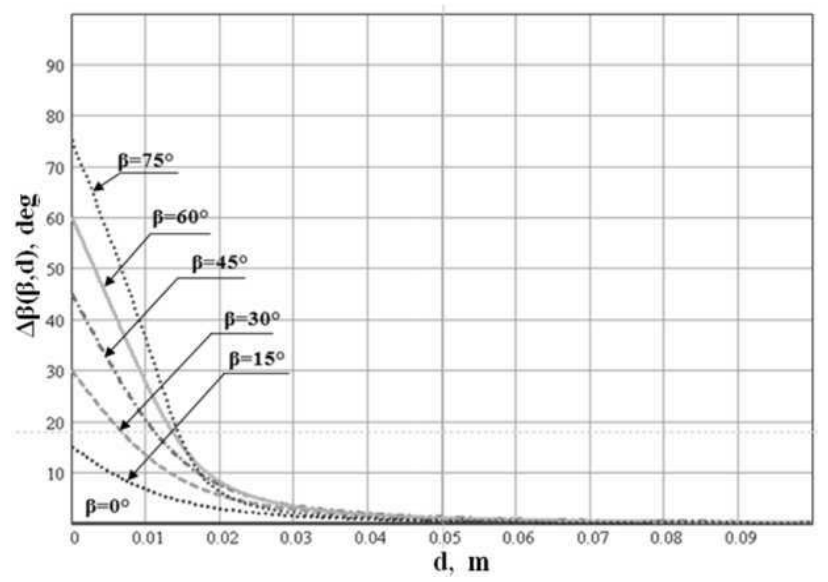

a)
To create verification procedure of implementation of equalities (36) we will consider the known [11] scheme of PDF LAA construction. This scheme includes two exact, but ambiguous scales of phase measuring with bases $L_{21}$ and $L_{32}$ (Fig.12) accordingly, and also two rough, but unambiguous scales with bases $L_{a}$ and $L_{b}$, where $L_{a}=L_{b}=0,5 \lambda$, which located inside and in the middle of proper ambiguous scales (Fig.12).

Then by analogy with (13) and (15) it is possible to note that signals on the phase detectors outputs $\mathrm{PD}_{1}-\mathrm{PD}_{5}$

$$
\begin{aligned}
& U_{\mathrm{PD}_{1}}=K_{D} U_{m} \cos \left(\Delta \varphi_{a}\right), \\
U_{\mathrm{PD}_{2}} & =K_{D} U_{m} \cos \left(\Delta \varphi_{21 \text { meas }}\right), \\
U_{\mathrm{PD}_{3}} & =K_{D} U_{m} \cos \left(\Delta \varphi_{b}\right),
\end{aligned}
$$

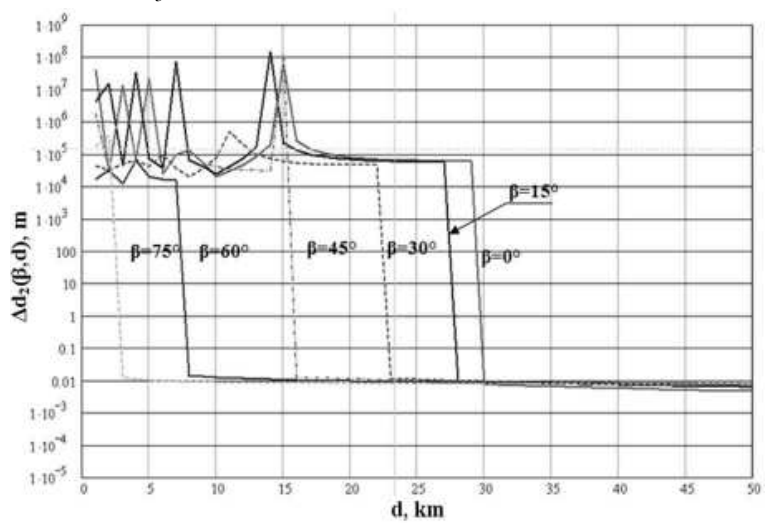

Fig.11 Distance error measuring as function of SOR distance and bearing angle

$$
\begin{gathered}
U_{\mathrm{PD}_{4}}=K_{D} U_{m} \cos \left(\Delta \varphi_{32 \text { meas }}\right), \\
U_{\mathrm{PD}_{5}}=K_{D} U_{m} \cos \left(\Delta \varphi_{31 \text { meas }}\right),
\end{gathered}
$$

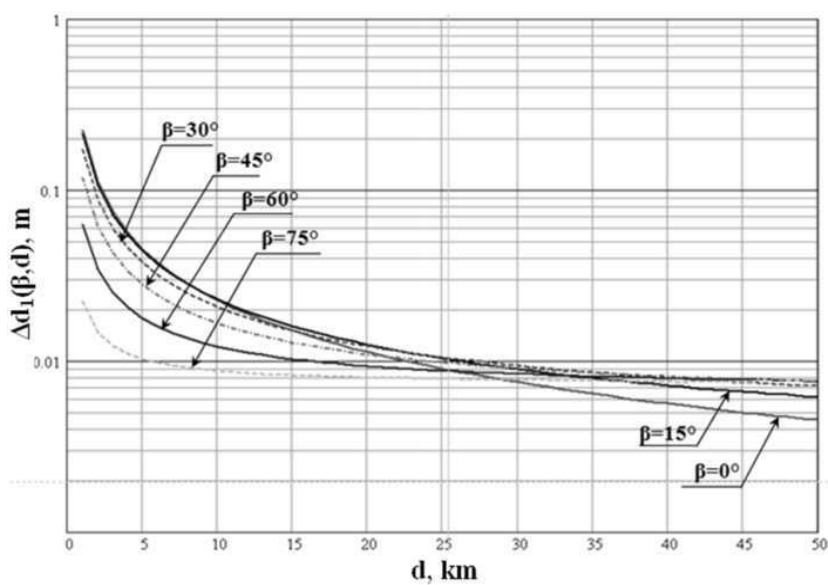

b)

Fig.10 a) The error of bearing angle measuring and b) distance error measuring as function of SOR distance and bearing angle. 


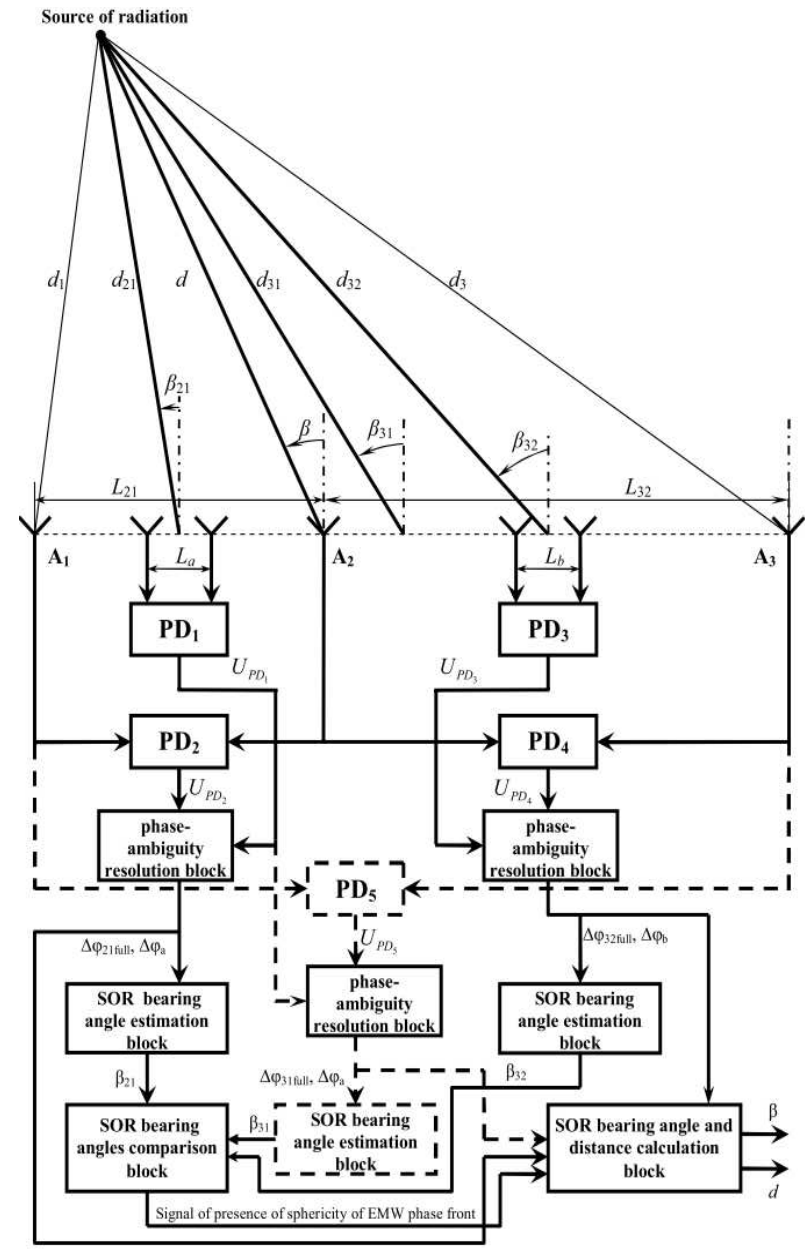

Fig.12 Phase direction-finder structure scheme with LAA where $\Delta \varphi_{a}, \Delta \varphi_{b}$ are phase shifts, measured with using unambiguous proper scales and equal

$$
\begin{gathered}
\Delta \varphi_{a}=\pi \sin \beta_{21}, \\
\Delta \varphi_{b}=\pi \sin \beta_{32} .
\end{gathered}
$$

According to (16), (39), (40) it is possible to write down that

$$
\begin{aligned}
& \Delta \varphi_{21 \text { full }}=\Delta \varphi_{21 \text { meas }}+2 \pi k_{21}, \\
& \Delta \varphi_{32 \text { full }}=\Delta \varphi_{32 \text { meas }}+2 \pi k_{32}, \\
& \Delta \varphi_{31 \text { full }}=\Delta \varphi_{31 \text { meas }}+2 \pi k_{31},
\end{aligned}
$$

where $k_{21}, k_{32}, k_{31}$ are coefficients, taking into account the number of complete periods, lost during measurements of difference of phases on the proper PDF bases, which by analogy with (7) will be equal to

$$
\begin{aligned}
& k_{21}=\left\langle\frac{1}{2 \pi}\left(\frac{L_{21}}{L_{a}} \Delta \varphi_{a}-\Delta \varphi_{21 \text { meas }}\right)\right\rangle, \\
& k_{32}=\left\langle\frac{1}{2 \pi}\left(\frac{L_{32}}{L_{b}} \Delta \varphi_{b}-\Delta \varphi_{32 \text { meas }}\right)\right\rangle,
\end{aligned}
$$

$$
k_{31}=\left\langle\frac{1}{2 \pi}\left(\frac{L_{31}}{L_{a}} \Delta \varphi_{a}-\Delta \varphi_{31 \text { meas }}\right)\right\rangle .
$$

Estimated bearing angles

$$
\begin{aligned}
& \beta_{21}=\arcsin \left(\frac{\lambda}{2 \pi L_{21}}\left(\Delta \varphi_{21 \text { full }}\right)\right)=\arcsin \left(\frac{\lambda}{2 \pi L_{21}}\left(\Delta \varphi_{21 \text { meas }}+2 \pi k_{21}\right)\right), \\
& \beta_{32}=\arcsin \left(\frac{\lambda}{2 \pi L_{32}}\left(\Delta \varphi_{32 \text { full }}\right)\right)=\arcsin \left(\frac{\lambda}{2 \pi L_{32}}\left(\Delta \varphi_{32 \text { meas }}+2 \pi k_{32}\right)\right), \\
& \beta_{31}=\arcsin \left(\frac{\lambda}{2 \pi L_{31}}\left(\Delta \varphi_{31 \text { full }}\right)\right)=\arcsin \left(\frac{\lambda}{2 \pi L_{31}}\left(\Delta \varphi_{31 \text { meas }}+2 \pi k_{31}\right)\right) .
\end{aligned}
$$

Resolving jointly equations (10) and (11) we will get that the bearing angle and distance to SOR with using EMW phase front curvature will be equal to

$$
\begin{gathered}
\beta=\arcsin \left(\frac{\lambda\left(\Delta \varphi_{32 \text { full }} L_{12}^{2}+\Delta \varphi_{21 \text { full }} L_{32}^{2}\right)}{2 \pi L_{12} L_{32}\left(L_{12}+L_{32}\right)}\right), \\
d=\frac{4 \pi^{2} L_{12}^{2} L_{32}^{2}\left(L_{12}+L_{32}\right)^{2}-\lambda^{2}\left(\Delta \varphi_{32 \text { full }} L_{12}^{2}+\Delta \varphi_{21 \text { fill }} L_{32}^{2}\right)^{2}}{4 \pi L_{32}\left(L_{12}+L_{32}\right) \lambda\left(\Delta \varphi_{32 \text { ful }} L_{12}^{2}-\Delta \varphi_{21 \text { full }} L_{12} L_{32}\right)} .
\end{gathered}
$$

Elements of bearing angle $\beta_{31}$ measuring scheme on a $L_{31}=L_{21}+L_{32}$ base are shown at Fig. 12. The usage of these elements is not mandatory if information received as a result of measurements on phase difference for bases $L_{21}$ and $L_{32}$ is sufficient.

More detailed variant of PDF scheme realization and description of its functioning is presented in [12].

\section{Phase direction-finder based on plane antenna array application}

In case of including second LAA which is orthogonal to first one into considered PDF antenna system [12], then LAA becomes a PAA. This enables measuring of SOR tilt angle $(\alpha)$ that actual for passive radar systems.

We will consider simplified scheme of antennas location for PAA according to [14] (Fig.13), that can be complemented with unambiguous bases, located in amounting to bases $b_{1}, b_{2}, b_{3}$, to eliminate phase errors.

It is easy to show that DFC formula for the case when EMW phase front is plane will look like

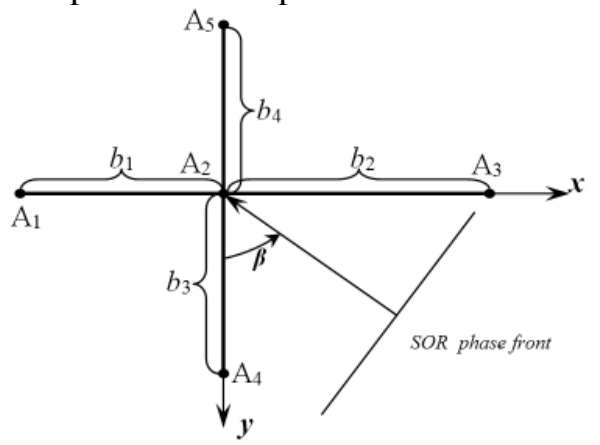

Fig.13 Simplified scheme of antennas location for PAA 


$$
F(\beta, \alpha)=\operatorname{tg}\left[\frac{\pi\left(b_{2}-b_{1}\right)}{\lambda} \cos \alpha \sin \beta\right]
$$

From where taking into account that for plane phase front

$$
\Delta \varphi_{42 \text { full }}=\frac{2 \pi}{\lambda} b_{3} \cos \beta \cos \alpha
$$

from (81) we will get that bearing angle equals

$$
\beta=\operatorname{arctg}\left(\frac{2 b_{3} \operatorname{arctg}(F(\beta, \alpha))}{\left(b_{1}-b_{2}\right) \Delta \varphi_{42 \text { full }}}\right)
$$

In its turn, SOR tilt angle will be equal to

$$
\alpha=\arccos \sqrt{\left(\frac{\lambda \operatorname{arctg}(F(\beta, \alpha))}{\pi\left(b_{1}-b_{2}\right)}\right)^{2}+\left(\frac{\lambda \Delta \varphi_{42 \text { full }}}{2 \pi b_{3}}\right)^{2}},
$$

where $\Delta \varphi_{42 \text { full }}=\Delta \varphi_{42 \text { meas }}+2 \pi k_{42}, \Delta \varphi_{42 \text { meas }}$ is the measured phase shift between antennas of $\mathrm{A}_{4}$ and $\mathrm{A}_{2}$, and $k_{42}$ is the number of periods, which was lost during measurements.

When EMW phase front curvature (see of equation (35) or (36)) is present, the angular SOR coordinates can be determined according to next equation, shown below. This equation was received with using above mentioned methods.

$$
\begin{aligned}
& \beta=\operatorname{arctg}\left(\frac{\left(b_{3} b_{4}^{2}+b_{3}^{2} b_{4}\right)\left(b_{2}^{2} \Delta \varphi_{12 \text { full }}+b_{1}^{2} \Delta \varphi_{23 \text { full }}\right)}{\left(b_{1} b_{2}^{2}+b_{1}^{2} b_{2}\right)\left(b_{3}^{2} \Delta \varphi_{25 \text { full }}+b_{4}^{2} \Delta \varphi_{42 \text { meas }}\right)}\right) \\
& \alpha=\arccos \left(\begin{array}{l}
\left(\frac{\left.\lambda\left(b_{2}^{2} \Delta \varphi_{12 \text { full }}+b_{1}^{2} \Delta \varphi_{23 \text { full }}\right)\right)^{2}}{2 \pi\left(b_{1} b_{2}^{2}+b_{1}^{2} b_{2}\right)}+\right. \\
+\left(\frac{\lambda\left(b_{3}^{2} \Delta \varphi_{25 \text { full }}+b_{4}^{2} \Delta \varphi_{42 \text { meas }}\right)}{2 \pi\left(b_{3} b_{4}^{2}+b_{3}^{2} b_{4}\right)}\right)^{2}
\end{array}\right)
\end{aligned}
$$

where $b_{4}=0,5 \lambda$ (Fig.13). Distance from SOR to PDF can be calculated with one of the below equations

$$
\begin{aligned}
& d \approx \frac{\pi b_{1}^{2}\left(1-\cos ^{2} \alpha \sin ^{2} \beta\right)}{\lambda \Delta \varphi_{12 \text { full }}-2 \pi b_{1} \cos \alpha \sin \beta}, \\
& d \approx \frac{\pi b_{2}^{2}\left(1-\cos ^{2} \alpha \sin ^{2} \beta\right)}{2 \pi b_{2} \cos \alpha \sin \beta-\lambda \Delta \varphi_{23 \text { full }}}, \\
& d \approx \frac{\pi b_{4}^{2}\left(1-\cos ^{2} \alpha \cos ^{2} \beta\right)}{\lambda \Delta \varphi_{42 \text { full }}-2 \pi b_{4} \cos \alpha \cos \beta},
\end{aligned}
$$

Variant of PDF scheme realization and description of his functioning in accordance with (80) - (88) is taken into account in the publication [14].

Forming of the unambiguous scale for phase measuring for three-element density-tapered sparse LAA can be carried out by application of harmonic signal frequency division schemes [13] if we talk about radiation of SOR harmonic signal.
There is $\delta<<1$ in formula (38). It means that the division of signal phase is equivalent to $\delta^{-1}$ times and problem for $\cos \left(\delta \Delta \varphi_{21}\right)$ and $\sin \left(\delta \Delta \varphi_{21}\right)$ finding can be solved by using three frequency dividers and two additional PDs. Thus, the first and third frequency dividers, which are connected in a parallel with the outputs of antennas of $\mathrm{A}_{1}$ and $\mathrm{A}_{2}$ (Fig.1), jointly with $\mathrm{PD}_{5}$ (the frequency dividers and PDs are not shown on Fig.1 (see [12])) form voltage

$$
U_{P D_{5}}=K_{D} K_{F D} U \cos \left(\delta \Delta \varphi_{21}\right),
$$

and the second and third frequency dividers, which are connected in a parallel with the output of antenna $A_{1}$ through first 90-degrees phase shifter and are also connected with exit of antenna $\mathrm{A}_{2}$ with $\mathrm{PD}_{6}$.

$$
U_{P D_{6}}=K_{D} K_{F D} U \sin \left(\delta \Delta \varphi_{21}\right),
$$

де $K_{F D}$ is the gains of the frequency dividers.

After that these voltage values for a multiplication product selection raise to the second power, summarize and the result of adding up stretches from under a square root. Formulae (89) and (90) divided by the received value which actually results in their normalization

$$
\begin{gathered}
\frac{U_{P D_{5}}}{K_{D} K_{F D} U}=\cos \left(\delta \Delta \varphi_{21}\right)=U_{\mathrm{PD}_{5}}^{\prime} \\
\frac{U_{P D_{6}}}{K_{D} K_{F D} U}=\sin \left(\delta \Delta \varphi_{21}\right)=\mathrm{U}_{\mathrm{PD}_{6}}
\end{gathered}
$$

Final verification of condition for plane EMW phase front is carried out in the DFC former. If equation (38) is executed, DFC forming procedure and procedure of bearing angle determination starts on it.

In case if equation (38) omission takes place, bearing angle must be determined from formula (13). But taking into account that distance is unknown, it is proposed to introduce voltage-contolled phase shifter in [15]. The maximal value of such shifter is proportional to deviation from equation (38), and a scale is gauged as function of SOR distance.

Phase shifter delays the harmonic signal phase for center antenna (Fig.1) to such phase value, that phases of signals from all three antennas could become identical at receivers outputs. It is equivalent to EMW plane phase front. The control of equation (38) is carried out in the process of harmonic signal phase adjusting. On achievement of necessary error closing, DFC is being forming again according to formula (1). Then bearing angle is determining, and the distance to SOR can be determined (in Fresnel zone) in accordance with the location of phase shifter. 


\section{Conclusions}

1. Failure to take into account EMW phase front curvature from SOR harmonic signal leads to errors of SOR coordinate calculation under conditions of its location in Fresnel zone and absence of other SORs.

2. During the process of SOR angular coordinates determination in Fresnel zone with use of EMW phase front curvature on the basis of PAA, it is necessary to execute consistently two operations: 1) to define the fact of presence of EMW phase front curvature; 2) to switch PDF from the mode of bearing and tilt angles estimation (when it is in plane phase front) to the mode of bearing and tilt angles estimation (and also distance to SOR if needed) with phase front curvature.

Knowledge of distance to SOR can be used in passive radar systems, in radio monitoring systems of radio interference sources which have bearing angles equal with useful SOR ones, but located on different distances from useful SOR (new method of antijamming which has not been applied yet in practice) [16]. This knowledge can also be used in mobile communication networks to strengthen signal level on certain distance, in vehicle control systems on the basis of the satellite navigation systems [17] etc.

3 . Taking into account the above-mentioned analysis relating to errors of bearing angle measurements in Fresnel zone (depending on the location of rough, but exact bases, for three-element sparse LAA) it is possible to conclude that their position doesn't impact on exactness of bearing angle measuring. But to support more exact determination of SOR distance they must be placed in the center of exact, but ambiguous bases. Talking about the case of SOR harmonic signal radiation, forming of unambiguous scale of phase measuring should be carry out with application of frequency division schemes.

\section{References}

[1] R.P. Bystrov, A.V. Sokolov, Passive radars: methods of objects detection (Radiotehnika, Moscow, 2008) [in Russian, ed. by R. Bystrov].

[2] D. I. Voskresenskiy E. V. Ovchinnikova, S.G. Kondrateva, P.A, Shmachilin Onboard active antenna arrays with digital signal processing. Prospects of development (21st International Crimean Conference Microwave \& telecommunication technology, Conference Proceedings, September 12-16, 2011, Sevastopol, Crimea, Ukraine)

[3] B.O. Karpenko, Y.A. Yakornov, G. L. Avdeyenko, I. L. Lipchevskaya, O.V. Mazurenko, The modern state of radio signals processing in the antenna systems of the base stations in wireless communication network. (Transactions of scientific papers of Military Institute of Kiev State University after named Taras Shevchenko, Vol.№27, Kiev,2010) [in Ukrainian]

[4] Honglin Hu, Yan Zhang, Jijun Luo. Distributed antenna systems : open architecture for future wireless communications. - New York: Auerbach Publications, 2007. - 490p.

[5] B. O. Karpenko, Y.A. Yakornov, G. L. Avdeyenko, I. L. Lipchevskaya, M.O. Kolomytsev, O.V, Mazurenko, Priority directions of development of radio signals adaptive processing for the efficiency increase of wireless communication network functioning with the distributed antenna systems (Transactions of scientific papers of Military Institute of Kiev State University after named Taras Shevchenko, Vol.№28, Kiev,2010) [in Ukrainian]

[6] I. Ya. Kremer, A. I. Kremer, V. M. Petrov et al., Space-Time Signals Processing (Radio i Svyaz', Moscow, 1984) [in Russian, ed. by I. Ya. Kremer].

[7] A. Fenn Adaptive antennas and phased arrays for radar and communications / Massachusetts Institute of Technology, Lincoln Laboratory - Artech House Inc., 2008. 389 p.

[8] G. L. Avdeyenko, V.I. Fedorov, Y. A. Yakornov, Determination of the radiation source location based on the electromagnetic wave's front curvature, Radioelectronics and communications systems, Vol.51, №3, 2008.

[9] V.I. Dikarev, I.N. Karelov, A.I. Zamarnin, Patent №2134429 (Russian Federation). Phase method for direction-finding, G01 S 3/00, G01 S 3/46, 1999.

[10] E.S. Bespalov, V.V. Kurgin, Patent №2138061 (Russian Federation). Phase radio direction-finder, G01 S 3/48, 1999.

[11] V.P. Denisov, D.V. Dubinin, Phase direction-finders: monograph (Tomsk State University of Control Systems and Radioelectronics, Tomsk, 2002)

[12] G. L. Avdeyenko, M.Y. Ilchenko, Y. A. Yakornov et al, Patent №57200 (Ukraine) Phase direction-finder, G01 S 3/00, 2011.

[13] V.F. Komarovich, V.V. Nikitchenko, Methods of the space processing of radio signals (Military Academy of the Signal Corps after named S. M. Budjonny, Leningrad, 1989).

[14] G. L. Avdeyenko, M. Y. Ilchenko, Y.A. Yakornov et al. Patent №64696 (Ukraine) Phase radio system for coordinate determination, G01S3/02, G01S3/00, $2011 \mathrm{p}$

[15] G. L. Avdeyenko, B. A. Karpenko, Y.A. Yakornov et al. Patent №56430 (Ukraine) Phase radio direction-finder, G01S3/02, G01S3/00, $2011 \mathrm{p}$.

[16] M.Y. Ilchenko, O.V. Mazurenko, Y.A. Yakornov, Patent №55415 Receive sparse adaptive antenna array, G01S3/00, H01Q3/00, 2010.

[17] G.L. Avdeyenko, M.V. Zhukova, Y. A. Yakornov et al, Patent №8150

(Ukraine) The system of mobile objects tracking with the usage of the global navigation satellite system's signals, G01S5/14, 2005. 
Авдєєнко Г.Л., Якорнов С. А.

Використання розподілених антенних систем для визначення в зоні Френеля координат джерела радіовипромінювання фазовим методом

Проблематика. Насьогодні в засобах пасивної радіолокації, багатофункціональних антенах і при організації якісного мобільного радіозв'язку у великих офісних приміщеннях, торгових центрах і спортивних спорудженнях широке поширення одержують розподілені антенні системи (РАС), що представляють собою сукупність антен і базових станцій з активними й пасивними ретрансляторами радіосигналів, взаємне розташування яких, як правило, підбирається експериментально за критерієм максимізації площі зони обслуговування. Для подальшого поліпшення якості послуг, у системах з РАC необхідно використовувати Smart-Антени, що відслідковують шляхом пеленгації місце розташування абонента, та збільшують при необхідності потужність випромінювання радіосигналу в напрямку на нього, тим самим мінімізуючи рівень завад у напрямку на інших абонентів. Амплітудні методи пеленгації в цьому випадку неприйнятні через відносно широкі характеристики спрямованості антен базових станцій, але актуальним стає використання фазових методів пеленгації, розвиток яких стримується багатопроменевістю поширення електромагнітних хвиль (ЕМХ) і великих помилок пеленгування через можливе знаходження абонента (далі ДРВ джерела радіовипромінювання) у зоні Френеля антенної системи пеленгатора, в якій має місце відхилення фазового фронту ЕМХ від плоского (кривизна).

Мета досліджень. Розгляд впливу сферичності (кривизни) фазового фронту ЕМХ ДРВ на точність визначення координат (дальність, пеленг тощо) ДРВ фазовими методами пеленгації на основі РАС, а також варіантів схемнотехнічних рішень для побудови фазових пеленгаторів по кривизні фазового фронту.

Методика реалізації. Для дослідження впливу кривизни фазового фронту на точність визначення координат ДРВ на підставі синтезованих аналітичних залежностей з використанням програми Мathcad 14 були проведені розрахунки пеленгаційних характеристик, помилки визначення фазових зсувів між антенними елементами фазового радіопеленгатора, а також помилки визначення дальності до ДРВ в зоні Френеля як функції дальності до ДРВ і його пеленга.

Результати досліджень. При визначенні кутових координат ДРВ в зоні Френеля по кривизні фазового фронту EMX на основі фазового пеленгатора з РАC, необхідно послідовно виконати 2 операції: 1) визначити факт наявності кривизни фронту ЕМХ від ДРВ; 2) переключити фазовий пеленгатор з режиму оцінки пеленга й кута місця для плоского фазового фронту, за необхідності в режим оцінки пеленга, кута місця, а також дальності до ДРВ по кривизні фронту ЕMX.

Аналіз помилок виміру пеленга, а також дальності до ДРВ в зоні Френеля залежно від місця розташування грубих, але точних вимірювальних баз для 3-х елементної РАС фазового пеленгатора позує, що воно практично не впливає на точність виміру пеленга ДРВ, але при вимірі дальності до ДРВ ці бази необхідно розміщувати в середині точних, але неоднозначних вимірювальних баз.

Висновки. Неврахування кривизни фронту ЕMХ ДРВ гармонійного сигналу призводить до помилки обчислення координат ДРВ за умови його знаходження в зоні Френеля й відсутності інших джерел ДРВ. Знання дальності до ДРВ можна використовувати в пасивній радіолокації, системах моніторингу джерел радіозавад, що перебувають на одному пеленгу з корисним ДРІ, але на різних дальностях, у системах мобільного зв'язку для підсилення рівня сигналу на певній дальності шляхом фокусування на цій дальності енергії ЕМХ, у системах диспетчеризації рухливого транспорту на основі супутникових радіонавігаційних систем.

Ключові слова: джерело радіовипромінювання; фазовий радіопеленгатор; кривизна; фазовий фронт; антенна решітка; пеленг; дальність.

Авдеенко Г.Л., Якорнов Е. А.

Использование распределенных антенных систем для определения в зоне Френеля координат источника радиоизлучения фазовым методом

Проблематика. В настоящее время в средствах пассивной радиолокации, многофункциональных антеннах и при организации качественной мобильной радиосвязи в больших офисных помещениях, торговых центрах и спортивных сооружениях широкое распространение получают распределенные антенные системы (РАС), представляющие собой совокупность антенн и базовых станций с активными и пассивными ретрансляторами радиосигналов, взаимное расположение которых, как правило, подбирается экспериментально по критерию максимизации площади зоны обслуживания. Для дальнейшего улучшения качества услуг, в системах с РАС необходимо использоватьSMART-антенны, отслеживающие путем пеленгации местоположение абонента и увеличивающие в случае необходимости мощность излучения радиосигнала в направлении на него, тем самым 
минимизируя уровень помех в направлении на других абонентов. Амплитудные методы пеленгации в данном случае неприемлемы из-за относительно широких характеристик направленности антенн базовых станций, но актуально использование фазовых методов пеленгации, развитие которых сдерживается многолучевостью распространения электромагнитных волн (ЭМВ) и больших ошибок пеленгования из-за возможного нахождения абонента (далее ИРИ источника радиоизлучения) в зоне Френеля антенной системы пеленгатора, в которой имеет место отклонение фазового фронта ЭМВ от плоского (кривизна).

Цель исследований. Рассмотрение влияния сферичности (кривизны) фазового фронта ЭМВ ИРИ на точностные характеристики определения координат (дальность, пеленг) ИРИ фазовыми методами пеленгации на основе РАС и вытекающих из этого вариантов схемно-технических решений фазовых пеленгаторов по кризизне фронта ЭМВ.

Методика реализации. Для исследования влияния кривизны фазового фронта на точность определения координат ИРИ на основании синтезированных аналитических зависимостей с использованием программы МаthСаd 14 были проведены расчеты пеленгационных характеристик, ошибки определения фазовых сдвигов между антенными элементами фазового радиопеленгатора, а также ошибки определения дальности до ИРИ в зоне Френеля как функции дальности до ИРИ и его пеленга.

Результаты исследований. При определении угловых координат ИРИ в зоне Френеля по кривизне фазового фронта ЭМВ на основе фазового пеленгатора с РАС, необходимо последовательно выполнить 2 операции: 1) определить факт наличия кривизны фронта ЭМВ от ИРИ; 2) перевести фазовый пеленгатор из режима оценки пеленга и угла места для плоского фазового фронта в случае необходимости в режим оценки пеленга, угла места, а также дальности до ИРИ по кривизне фронта ЭМВ.

Анализ ошибок измерения пеленга, а также дальности до ИРИ в зоне Френеля в зависимости от места расположения грубых, но точных измерительных баз для 3-х элементной РАС фазового пеленгатора показывает, что оно практически не влияет на точность измерения пеленга ИРИ, но при измерении дальности до ИРИ эти базы необходимо размещать в середине точных, но неоднозначных измерительных баз.

Выводы. Неучёт кривизны фронта ЭМВ ИРИ гармонического сигнала ведёт к ошибке вычисления координат ИРИ при условии его нахождения в зоне Френеля и отсутствии других источников ИРИ. Знание дальности до ИРИ можно использовать в пассивной радиолокации, системах мониторинга источников радиопомех, находящихся на одном пеленге с полезным ИРИ, но на разных дальностях, в системах мобильной связи для усиления уровня сигнала на определенной дальности путем фокусировки на этой дальности энергии ЭМВ, в системах диспетчеризации подвижного транспорта на основе спутниковых радионавигационных систем.

Ключевые слова: источник радиоизлучения; фазовый радиопеленгатор; кривизна; фазовый фронт; антенная решетка; пеленг; дальность. 